\title{
The Perception of EFL High School Students in Using of Computer Technology in the Process of Learning: Merits and Demerits
}

\author{
Siros Izadpanah \\ Department of English Language Teaching, Zanjan Branch, Islamic Azad University, Zanjan, Iran \\ E-mail: cyrosizadpanah@iauz.ac.ir \\ Mansooreh Alavi (Corresponding author) \\ Department of English Language Teaching, Zanjan Branch, Islamic Azad University, Zanjan, Iran \\ E-mail: alavi.m64@gamil.com
}

Doi:10.7575/aiac.alls.v.7n.3p.146

URL: http://dx.doi.org/10.7575/aiac.alls.v.7n.3p.146
Received: 10/01/2016

Accepted: 15/03/2016

\begin{abstract}
Recent developments in the field of computer technology have led to a renewed interest in the process of learning. In order to investigate EFL learners' perception of technology use, a mixed method design was used to explore students' attitude. Quantitative data was collected through questionnaires and qualitative data using open-ended questions. The questionnaire was distributed in two different high schools (one male and one female) in Zanjan, 2015. Participants were 340 high school students who filled in CALLAI questionnaire. The data of the questionnaire was analysed using Statistical Packages for Social Sciences (SPSS) Version 20. Descriptive statistics including frequencies and percentages were used to analyze questionnaire items. Data gathered from open-ended questions was analysed using qualitative data analysis software NVivo 8.0. It was found that students had positive attitude toward facilitation of English learning in the classroom through computer technology. Our objective was to explore students' perceptions of technology usage in high schools. The implication of this study was that students, with prior experience in technology, might benefit more from technology use in education. Furthermore, it could be guidance for teachers to better understand world of technology and recognize possible barriers to integration of technology.
\end{abstract}

Keywords: Advantages of Computer Technology, Computer and EFL Teaching, EFL High School Students, English learning, Perceptions of EFL learners

\section{Introduction}

Computer technology is an important component in education, and plays a key role in English language learning. It has become a significant topic of interest at community of high schools, particularly with its promises of conveniences in time and space as well as opportunities to access vast amounts of information and use innovative ways of delivering and accessing course content. In a few short years, the computer technology has made unprecedented inroads into high schools around the world. The advent of computer technology in EFL instruction has led to significant changes in teachers' approaches, methodologies, and strategies of teaching foreign language like English.

Previous studies on perception of EFL high school students in using of computer technology in the process of learning have focused mostly on administrative processes. Given that studies on digital issues in the community of high school student population are rare and that additional research supports differences in demographics between community of high school student populations and four year high school student populations, it is important to look further into the community of high school students population to observe the impact of demographics such as household income, age, gender, primary language, number of dependents, employment status, educational levels, and technology access history as well as current access on computer technology competence, confidence and attitudes toward computer technology.

So far, however, there has been little discussion about the perception of EFL high school students in using of computer technology in the process of learning. The collected data from this study might be beneficial for educators and instructors in their instructional decisions. Furthermore, it could be guidance for teachers to better understand world of technology and recognize possible barriers to integration of technology. This contrast of the community high school students' merits and demerits of technology use for learning creates the need for a more direct study to further delineate issues, particularly from a student-cantered perspective. The question has been repeatedly raised: why focus on the computer and no other devices? First, the computer is by far the most widely used device in schools around the world. According to Khaddage (2013), the computer has captured over $75 \%$ of the education market worldwide. In Canada, it accounts for over $90 \%$ of the education market. The computer is also one of the most advanced technologies: it supports over 300,000 specifically designed applications (King \& Bass, 2013). 
Our aim was to shed scientific and empirical light on these issues in order to help schools, teachers, and students use the computer for learning in more reflective and educational ways. The purpose of this study was to explore students' perceptions of technology usage in high schools. Additionally, this study attempted to explore how EFL students envisage technology usage in a classroom setting and investigate the effect of technology integration in their learning.

\subsection{Review of literature}

Technology has been part of our life for thousands of years. In the field of foreign language teaching, every type of language teaching methods and techniques has exploited its own technological tools nearly. Warschauer and Meskill (2000) stated that language classrooms managed by grammar translation method used a very common and primitive technology: blackboard (as cited in Sadegh Pour, 2013). Although use of technology into foreign language classrooms started over 1950s, it did not play an important role in teaching and learning process of EFL because of the problems related to technological structures (Alsied\& Pathan, 2013). According to Riasati, Allahyar and Tan (2012), integration of technology improves students' engagement and enhances their motivation in accomplishing their tasks.

Oz, Demirezen, and Pourfeiz (2015) investigated the relationship between computer literacy, attitudes towards foreign language learning and computer-assisted language learning. Participants were 123 university students majoring in English as a foreign language. With regard to data collection, two different questionnaires, Attitudes towards Foreign Language Learning (A-FLL), Scale and the Attitudes towards Computer-Assisted Language Learning (A-CALL) were used. Findings revealed positive correlations between A-FLL and A-CALL. In addition, it was found that gender and computer literacy play a significant role in attitude toward CALL.

Kitchakarn (2015) investigated the EFL students' attitudes toward use of computers in a private university on their language learning process. Regarding this, some factors including gender, experience of using computers, and perceived abilities in using programs were taken into account. In order to collect data, 192 undergraduate students filled in a questionnaire. Findings of the study revealed that computer was considered a useful tool on learning process of students. Effect of gender was not found to be significant on students' attitude, while abilities to use program had effect on students' attitude.

Kalanzadeh, Soleimani, and Bakhtiarvand (2014) examined the relationship between Iranians EFL students' motivation and use of technology in university classroom. For the purpose of data collection, 60 Iranian EFL students from different courses answered the questionnaire items. Findings revealed that university students maintained positive attitude toward technology use in their English classes. It also found that there is a relationship between learning English and using technology in EFL classroom.

In a similar study, Afshari, Ghavifekr, Siraj, and Jing (2013) examined the university students' attitudes toward use of computer-assisted language learning. A survey questionnaire was used to collect data from 100 students at university of Malaya. Students showed a moderate attitude toward CALL. In addition, three predictors: perceived ease of use, perceived usefulness, and subjective norms were the most effective factors on computer attitude.

Chen and Kessler (2013) examined how students used tablets for informal language learning in order to consider their attitudes. Participants of study were 10 English major students of university. Findings of the study showed that students had positive attitude toward effectiveness of tablets as a learning tool. Furthermore, it was found that students needed more chances to be autonomous on their informal learning out of classroom.

Nguyen and Tri (2014) explored use of ICT among EFL university students on their English learning programs. Data collected through questionnaires showed that English major students use ICT for personal purposes more than learning purposes. Regarding the expectation factor, students believed that ICT should be used more in classroom in order to improve their learning process.

Bramley (2015) focused on female students' reaction to iPods and eBooks in one of Japanese universities. A survey was used to collect data regarding students' reactions. It was aimed to assess how students and teachers use technology in and out of classroom and what improvements and trainings required. Participants were 351 students in their English discussion courses. Generally, it was found that students realized uses of iPods' and kept positive reactions to both iPods and eBooks.

Warschauer (2013) conducted a study to compare students' participation in a face-to-face discussion and electronic discussion. In addition, amount of each student's participation was correlated by factors including language ability, nationality, time in the U.S., and students' attitude. Data related to attitudes were collected via an anonymous survey. Findings showed that students had more tendencies in electronic discussions.

Learning through technology has become a significant topic interest at community schools, particularly with its promises of conveniences in time and space as well as opportunities to access vast amounts of information and to use innovative ways of delivering and accessing course content. Previous researches on the application of technology issues in community school have been scarce and have focused mostly on administrative process.

\section{Method}

\subsection{Participants}

Population of the study was students from two high schools (one male, and another female high school) in Zanjan, Iran. The entire population consisted of 638 high school students- 245 males and 393 females and their ages were 14 to 17 . In order to determine the number of target sample, Cochran formula was used. The target sample of the study consisted of 
147 male and 193 female students. In order to select sample of students from first, second, and third grade of high school, proportionate stratified random sampling was applied. The final sample size of the study was selected randomly from first, second, and third grade stratum by sampling fraction of $1 / 2$. The final sample size included 87 first grade, 122 second grade, and 134 third grade students.

\subsection{Instruments}

In order to collect data, a validated questionnaire was used (see Appendix A).Aryadoust, Mehran, and Alizadeh (2015) validated CALLAI (CALL attitude instrument). The structure of the questionnaire was grounded on affective, behavioral, and language skills components.

In order to get in-depth results and better understand the students' attitude, open-ended questions were included in the questionnaire. Questions were designed parallel with questionnaire items and based on previous studies in the literature.

\subsection{Procedure}

In the present study, a mixed method design was used. According to Mackey and Gass (2005), mixed method is a research design in which researchers exploit and discuss both quantitative and qualitative data in the same study. Traditionally, qualitative research is defined by distinguishing from quantitative research. Normally, these distinctions are specified by dichotomies including words/numbers, subjective/objective, specific/generalizable, and descriptive/technical (Richards, 2009; Zacharias, 2012). After one semester learning English through CALL, students filled in CALLAI questionnaire and responded to open-ended questions.

After collecting and evaluating questionnaires, the highest and lowest attitude questionnaire were put away and those students' responses to open-ended questions i.e. one standard deviation above means and one standard deviation below the means were analyzed. Overall, 60 open-ended questionnaires were in the range from which 45 were filled appropriately. In order to establish validity of the gathered data of open-ended questions, a variety of techniques were used:
1. Member checking
2. Peer debriefing
3. Researches credibility

\section{Results}

Collected data of questionnaires was analyzed using descriptive statistics by Statistical Packages for Social Sciences (SPSS) Version 20.

Table 1. Descriptive Statistics of Questionnaire Items

\begin{tabular}{|c|c|c|c|c|c|c|c|c|c|c|}
\hline \multirow[b]{2}{*}{ Question Items } & \multicolumn{2}{|c|}{ Strongly Agree } & \multicolumn{2}{|c|}{ Agree } & \multicolumn{2}{|c|}{ Disagree } & \multicolumn{2}{|c|}{$\begin{array}{l}\text { Strongly } \\
\text { Disagree }\end{array}$} & \multicolumn{2}{|l|}{ Total } \\
\hline & $\mathrm{F}$ & $\%$ & $\mathrm{~F}$ & $\%$ & $\mathrm{~F}$ & $\%$ & $\mathrm{~F}$ & $\%$ & $\mathrm{~F}$ & $\%$ \\
\hline $\begin{array}{l}\text { 1. Computer is a useful tool to access } \\
\text { various types of English materials for } \\
\text { reading. } \\
\text { 2. CALL helps me improve my }\end{array}$ & 93 & 32.7 & 139 & 48.9 & 25 & 8.8 & 16 & 5.6 & 273 & 96.1 \\
\hline listening skills. & 121 & 42.6 & 115 & 40.5 & 31 & 10.9 & 13 & 4.6 & 280 & 98.6 \\
\hline $\begin{array}{l}\text { 3. CALL makes lessons more } \\
\text { interesting than traditional English } \\
\text { instruction }\end{array}$ & 70 & 24.6 & 91 & 32.0 & 71 & 25.0 & 34 & 12.0 & 266 & 93.7 \\
\hline $\begin{array}{l}\text { 4. Computers make English learning } \\
\text { easier for independent learning. }\end{array}$ & 41 & 14.4 & 126 & 44.4 & 84 & 29.6 & 28 & 9.9 & 279 & 98.2 \\
\hline $\begin{array}{l}\text { 5. Computers make English learning } \\
\text { easier in the classroom. }\end{array}$ & 65 & 22.9 & 148 & 52.1 & 50 & 17.6 & 15 & 5.3 & 278 & 97.9 \\
\hline $\begin{array}{l}\text { 6. CALL helps me improve my } \\
\text { speaking skills. }\end{array}$ & 82 & 28.9 & 135 & 47.5 & 45 & 15.8 & 16 & 5.6 & 278 & 97.9 \\
\hline $\begin{array}{l}\text { 7. Computer is a useful tool for } \\
\text { developing writing tools. }\end{array}$ & 48 & 16.9 & 108 & 38.0 & 75 & 26.4 & 41 & 14.4 & 272 & 95.8 \\
\hline $\begin{array}{l}\text { 8. I like learning a new language by } \\
\text { computer. }\end{array}$ & 67 & 23.6 & 102 & 35.9 & 67 & 23.6 & 40 & 14.1 & 276 & 97.2 \\
\hline $\begin{array}{l}\text { 9. I can get more useful feedback in } \\
\text { CALL lessons. }\end{array}$ & 45 & 15.8 & 138 & 48.6 & 71 & 25.0 & 25 & 8.8 & 279 & 98.2 \\
\hline $\begin{array}{l}\text { 10. I can get more useful feedback in } \\
\text { CALL lessons. }\end{array}$ & 66 & 23.2 & 149 & 52.5 & 48 & 16.9 & 11 & 3.9 & 274 & 96.5 \\
\hline $\begin{array}{l}\text { 11. I am confident about working } \\
\text { with computers. }\end{array}$ & 58 & 20.4 & 134 & 47.2 & 63 & 22.2 & 16 & 5.6 & 271 & 95.4 \\
\hline
\end{tabular}


12. I often use computers to do my 23

8.1

58

20.4

117

41.2

76

13. CALL helps me enlarge my 80 vocabulary knowledge.

14. It is essential for English 89 language learners to master computer skills.

15. Using computer tools to learn English is a great advantage over traditional methods.

16. CALL is a stress-free 67 environment to learn English.

17. Learning English through 23 computers is not necessary.

18. I find that using computers does 9 not help my English learning.

19. The use of computers can help 69 improve my communication skills.

20. Using a computer makes language lessons more interesting to me.

21. CALL helps me develop my 43 grammar.

22. CALL makes me feel tense and 13 uncomfortable.

23. Communicating by e-mail is 36 good way to improve my English.

24. I need training in using language 2 learning software programs.

25. Chatting with native English speakers on the internet is helpful for learning English.

26. I can cover more material on my 56 own when I study English with computers.

27. Computers will dehumanize 58 learning English.

Note. F: Frequency, \%: Percentage

$\begin{array}{rrrrrrrrr}28.2 & 134 & 47.2 & 47 & 16.5 & 15 & 5.3 & 277 & 97.5 \\ 31.3 & 138 & 48.6 & 38 & 13.4 & 11 & 3.9 & 276 & 97.2\end{array}$

$\begin{array}{lllllllll}21.5 & 130 & 45.8 & 68 & 23.9 & 16 & 5.6 & 275 & 96.8\end{array}$

$\begin{array}{lllllllll}23.6 & 124 & 43.7 & 61 & 21.5 & 22 & 7.7 & 274 & 96.5\end{array}$

$\begin{array}{lllllllll}8.1 & 84 & 29.6 & 103 & 36.3 & 68 & 23.9 & 278 & 97.9\end{array}$

$\begin{array}{lllllllll}3.2 & 21 & 7.4 & 137 & 48.2 & 115 & 40.5 & 282 & 99.3\end{array}$

$\begin{array}{lllllllll}24.3 & 158 & 55.6 & 39 & 13.7 & 11 & 3.9 & 277 & 97.5\end{array}$

$\begin{array}{lllllllll}21.1 & 147 & 51.8 & 56 & 19.7 & 19 & 6.7 & 282 & 99.3\end{array}$

$\begin{array}{lllllllll}15.1 & 121 & 42.6 & 78 & 27.5 & 29 & 10.2 & 271 & 95.4\end{array}$

$\begin{array}{lllllllll}4.6 & 29 & 10.2 & 125 & 44.0 & 110 & 38.7 & 277 & 97.5\end{array}$

$\begin{array}{lllllllll}12.7 & 124 & 43.7 & 74 & 26.1 & 43 & 15.1 & 277 & 97.5\end{array}$

$\begin{array}{lllllllll}9.5 & 87 & 30.6 & 96 & 33.8 & 68 & 23.9 & 278 & 97.9\end{array}$

$\begin{array}{lllllllll}40.1 & 114 & 40.1 & 31 & 10.9 & 20 & 7.0 & 279 & 98.2\end{array}$

$\begin{array}{lllllllll}19.7 & 153 & 53.9 & 46 & 16.2 & 21 & 7.4 & 276 & 97.2\end{array}$

$\begin{array}{lllllllll}20.4 & 106 & 37.3 & 69 & 24.3 & 42 & 14.8 & 275 & 96.8\end{array}$

According to language skills component of the questionnaire, students answered to seven questions. Items 1, 2, 6, 7, 13, 19, and 21 addressed to reading, listening, speaking, writing, and vocabulary, communication, and grammar skills, respectively. Overall, it can be seen that $81.6 \%, 83.1 \%, 76.4 \%, 54.9 \%, 75.4 \%, 79.9 \%$, and $57.7 \%$ of participants strongly agreed and agreed that computer technology is helpful in learning reading, listening, speaking, writing, vocabulary knowledge, communication, and grammar skills, respectively.

Behavioural and affective components of the questionnaire addressed to usefulness, facility, necessity of CALL and learners independence, anxiety, eagerness, and attraction of CALL. Students strongly agreed and agreed that computers make independent learning easier (58.8\%), make learning English easier in the classroom (75\%), show advantage of English learning through computer technology over traditional methods (67.3\%). Regarding the use of computer technology to do homework, students showed $68 \%$ disagreement $(26.8 \%$ strongly disagree and $41.2 \%$ disagree $)$ with use of computer doing their homework. It might be due to that there is not enough CALL homework in the syllabus of English classrooms. More than half of participants (75\%) strongly agreed and agreed with usefulness of computer in correcting their mistakes and providing useful feedback. About $80 \%$ of participants showed their agreement strongly and moderately toward necessity of computer skills for English language learners. A majority of participants (88.7\%) strongly disagreed and disagreed with question 18 which showed computer does not help learners' English learning. Questions 23,25 , and 26 showed $56.4 \%, 80.2 \%$, and $73.6 \%$ of students' agreement moderately and strongly toward usefulness of email, chatting and computer technology on learning English.

Rest 8 questions of the questionnaire were related to affective component including anxiety, eagerness, and attraction toward computer technology. Regarding attraction $56.6 \%, 59.5 \%$, and $72.9 \%$ of participants strongly agreed and agreed with question 3, 8, and 20 on that learning a new language and English lessons are interesting more than traditional 
methods. Furthermore, students showed their strong and moderate agreement (motivation, $64.4 \%$; self-confidence, $67.6 \%)$ with gaining motivation and self-confidence using computer technology. Participants $(67.3 \%)$ strongly agreed and agreed that CALL provides a stress-free environment. Also, a majority of participants (82.7\%) strongly and moderately disagreed that CALL makes them feel uncomfortable and tense. Finally, 57.7\% of students strongly agreed and agreed that computers dehumanize learning English and fewer students (39.1\%) showed their disagreement with dehumanizing effect of computers on learning English.

Qualitative study was used to gain more in-depth results. Transcript of data was analyzed in order to identify themes and participants' perception of using technology in their learning process. Then NVivo 8.0 qualitative analysis software was used to organize and code emerging themes.

Question 1: What type of technology user are you? Advanced, average, or beginner?

The first question was intended to start the process of qualitative study. Frequency of participants was provided in Table 2.

Table 2. Type of Technology User

\begin{tabular}{llll}
\hline Level & Percentage of participants & $\begin{array}{l}\text { Number of participants } \\
(\mathrm{n}=45)\end{array}$ & Number of references \\
\hline Advanced & $22.22 \%$ & 10 & 10 \\
Average & $62.2 \%$ & 28 & 28 \\
Beginner & $15.55 \%$ & 7 & 7 \\
\hline
\end{tabular}

Regarding first question, 28 participants, $62.2 \%$ of sample, referenced themselves as average user of technology. In addition, 10 out of 45 participants $(22.22 \%)$ considered themselves as advanced user and the seven remainder of sample $(15.55 \%)$ referenced themselves as beginner user of technology.

Question 2: What types of electronic devices do you use in your daily life?

Question 2 addressed to familiarity of participants with technological devices. Table 3 shows the emerging subthemes of question 2 .

Table 3. Types of Electronic Devices Used by Sample

\begin{tabular}{llll}
\hline Electronic Devices & Percentage of participants & $\begin{array}{l}\text { Number of participants } \\
(\mathrm{n}=45)\end{array}$ & Number of references \\
\hline IPod & $11.11 \%$ & 5 & 5 \\
Smart phone & $15.55 \%$ & 7 & 7 \\
Mp3 player & $22.22 \%$ & 10 & 10 \\
Lap top & $33.33 \%$ & 15 & 15 \\
Tablet & $35.55 \%$ & 18 & 16 \\
Cell phone & $66.66 \%$ & 30 & 30 \\
Personal computer & $71.11 \%$ & 32 & 32 \\
\hline
\end{tabular}

As it can be seen in Table 3,11.11\% of participants referenced that they use IPod in their daily life. Of 45 participants, seven students (15.55\%) referenced to use of smart phone in their everyday life. Also, $22.22 \%$ of the sample referred to use of Mp3 player in their daily life. Next electronic device used by participants was lap top which was referenced 15 times by $33.33 \%$ of participants. Tablet was referenced 16 times by $35.55 \%$ of the respondents. One of the most used electronic devices by participants was cell phone which referenced 30 times (66.66\%). Another most referenced device (32 times) was personal computer which was used by $71.11 \%$ of participants.

Question 3: How do you use technology for English home works?

This question intended to identify different ways of using technology by students doing their homework. Table 4 indicates students' use of technology doing homework with emerging sub-themes.

Table 4. Technology Use for English Homework

\begin{tabular}{llll}
\hline Type of technology & Percentage of participants & $\begin{array}{l}\text { Number of participants } \\
(\mathrm{N}=45)\end{array}$ & Number of references \\
\hline Not used & $6.66 \%$ & 3 & 3 \\
Power point & $8.88 \%$ & 4 & 4 \\
Searching websites & $13.33 \%$ & 6 & 6 \\
Watching English movies & $11.11 \%$ & 5 & 5 \\
Dictionary & $28.88 \%$ & 13 & 13 \\
Language learning & $31.11 \%$ & 14 & 14 \\
software & & & 20 \\
Listening activities & $44.44 \%$ & 20 & \\
\hline
\end{tabular}


As it can be seen in the Table 4, three of participants $(6.66 \%)$, four $(8.88 \%)$, six $(13.33 \%)$, five $(11.11 \%)$ referred not to use technology doing their homework, making power point for classroom projects, searching websites in order to find information relating to their homework, reported watching English movies as homework to improve their speaking skill. Use of online and cell phone dictionaries were referred $28.88 \%$ by 13 participants. Also, 14 participants (31.11\%) referred to use of language learning software to improve their English. The last sub-theme regarding technology use for homework was doing listening activities. Among participants 20 (44.44\%) referred listening to songs, dialogs, and other materials to do their homework. Listening was the main homework activity referenced by students.

Question 4 and 5: What are some major obstacles to using technology in your school? How could your school make it easier for you to work electronically?

Students answered to these questions simultaneously since that, the questions are inter-related. Due to this, questions 4 and 5 were coded and analyzed in the same node by NVivo software. The result was included in Table 5 and Table 6.

Table 5. Major Obstacles to Using Technology in School

\begin{tabular}{llll}
\hline Obstacles & Percentage of participants & $\begin{array}{l}\text { Number of participants } \\
(\mathrm{n}=45)\end{array}$ & Number of references \\
\hline Lack of facilities & $100 \%$ & 45 & 45 \\
Computer and lap top & $84.44 \%$ & 38 & 40 \\
Projectors & $77.77 \%$ & 35 & 38 \\
Access to internet & $44.44 \%$ & 20 & 22 \\
Limitations and rules & $44.44 \%$ & 20 & 21 \\
Filtering & $13.33 \%$ & 6 & 8 \\
\hline
\end{tabular}

High school students $(100 \%, 45$ out of 45 participants) perceived lack of facilities as a major obstacle of using technology at their high school. Out of 45 participants, 38 (84.44\%), 35 (77.77\%) mentioned lack of computers and lap tops in each class, and projectors, respectively. In addition, low speed of internet and limitation of access to internet (44.44\%), limitations and rules of school (44.44\%) were discussed 22and 20 times by 20 participants. Furthermore, participants referred to as obstacle. Students explained that filtering sites $(13.33 \%)$ prevent them to access the information they need for school works.

Table 6. Working Electronically Easier

\begin{tabular}{llll}
\hline Ways of easy working & Percentage of participants & $\begin{array}{l}\text { Number of participants } \\
(\mathrm{n}=45)\end{array}$ & Number of references \\
\hline Providing more facilities & $88.88 \%$ & 40 & 45 \\
Removing limitations & $55.55 \%$ & 25 & 25 \\
Dedicating more time on & $33.33 \%$ & 15 & 15 \\
technology use & & & 11 \\
Holding training courses & $20 \%$ & 9 & \\
\hline
\end{tabular}

As it can be seen in Table 6, students' sample (88.88\%) 45 times signified that providing more facilities make working and learning with technology easier. $25(55.55 \%)$ perceived that removing limitations and rules make working with technology easier. In addition, 15 students referenced 15 times to limited time of using technology in their learning process. In other words, $33.33 \%$ of participants explained that school should dedicate more time on using technology in the learning process of English. The least referenced sub-theme (20\%) was holding computer training courses for students and teachers.

Question 6: In your opinion, which language skills or knowledge can be improved through technology devices? Can you give reasons?

The question above was in relation with the nature of community high school student's experiences using computer technology in the process of learning. The result of this question was shown in Table 7.

Table 7. Language Skills Improvement by Technology

\begin{tabular}{llll}
\hline Language skills & Percentage of participants & $\begin{array}{l}\text { Number of participants } \\
(\mathrm{n}=45)\end{array}$ & Number of references \\
\hline Listening & $66.66 \%$ & 30 & 38 \\
Speaking & $53.33 \%$ & 24 & 30 \\
Vocabulary & $26.66 \%$ & 12 & 13 \\
All language skills & $15.55 \%$ & 7 & 17 \\
Pronunciation & $13.33 \%$ & 6 & 7 \\
Grammar & $11.11 \%$ & 5 & 7 \\
Writing & $6.66 \%$ & 3 & 7 \\
Reading & $4.44 \%$ & 2 & 8 \\
\hline
\end{tabular}


Listening improvement was mentioned38 times by 30 students $(66.66 \%)$. More than half of participants $(53.33 \%)$ stated30 times that speaking and communication skills improve by using computer technology and watching movies. Additionally, participants referred 13 times to improvement of vocabulary knowledge through using computer, internet, and online dictionaries. Among 45 participants, seven of students (15.55\%) reported that all language skills can be improved by technology use. Six students (13.33\%) referred seven times that pronunciation improves by listening activities through computer and internet. Only five students (11.11\%) referred to grammar enhancement through computer and technology use. Finally, the least mentioned skills were referred by three and two participants for writing and reading skills, respectively

Question 7: What are the advantages and disadvantages of using technology programs in language instruction?

Answers of this question are associated with second research question community high school student's perception of benefits and challenges of use of computer technology in the process of learning. The result of this question was presented in Table 8 .

Table 8. Advantages and Disadvantages of Using Technology Programs in Language Instruction

\begin{tabular}{llll}
\hline $\begin{array}{l}\text { Advantages and } \\
\text { disadvantages }\end{array}$ & Percentage of participants & $\begin{array}{l}\text { Number of participants } \\
(\mathrm{n}=45)\end{array}$ & Number of references \\
\hline Effectiveness & $66.66 \%$ & 30 & 37 \\
Useful & $48.88 \%$ & 22 & 30 \\
Easy learning & $33.33 \%$ & 15 & 18 \\
Speed up learning & $31.11 \%$ & 14 & 15 \\
No disadvantage & $17.77 \%$ & 8 & 11 \\
Time saving & $17.77 \%$ & 8 & 10 \\
Diverse learning methods & $17.77 \%$ & 8 & 9 \\
Negative effect on health & & & 40 \\
Feelings & $62.22 \%$ & 28 & 21 \\
Enjoyable & $37.77 \%$ & 17 & 16 \\
Attractive & $31.11 \%$ & 14 & 6 \\
Motivation & $11.11 \%$ & 5 & \\
Real like & 14 & 5 & \\
\hline
\end{tabular}

Regarding the seventh question, two main themes of effectiveness and feelings emerged with seven and four subthemes, respectively. Out of 45 students, 30 students (66.66\%), 22 students (48.88\%), 15 students (33.33\%) referred to usefulness, easier learning, and faster learning of computer technology in language learning process. Regarding disadvantages, 14 students $(31.11 \%)$ referenced 15 times that use of technology in language instruction does not have any disadvantage. Eight students (17.77\%) referred to saving time by using technology in language learning process. Moreover, eight students referred 10 times to diversity and variety of learning methods by using technology. Regarding disadvantage of technology use in language instruction, eight participants only indicated 9 times to negative effect of technology use on physical health and vision. It was insinuated by $28(66.22 \%), 17(37.77 \%)$ students that technology makes learning English enjoyable and attractive. It was also implied16 times by 14 students (31.11\%) that use of computer technology motivates learners. In contrast to positive feelings of some students, five (11.11\%) students referenced that technology use in language instruction does not look like to real and natural learning environment.

\section{Discussion}

Overall, the results of both questionnaires and open-ended questions revealed that high school students perceive use of technology moderately positive in their learning process. Results of the open-ended questions were consistent with results of the questionnaire in many facets. In addition, there were slight differences between results of open-ended questions and questionnaire study. Like results of the questionnaire, high percent of respondents to open-ended questions reported that their listening, speaking, and communication skills improves through using technological tools. In addition, students showed moderate positive attitude toward improvement of vocabulary knowledge and pronunciation. However, reading skill dedicated a high mean score based on questionnaire results, open-ended questions results showed low mean score of reading improvement through technology use.

Findings of the study with regard to use of technology and its effect on language skills were in line with some of previous studies (Kalanzadeh, Soleimani \& Bakhtiarvand, 2014; Kitchakarn, 2015; Nguyen \& Tri, 2014). Kalanzadeh, Soleimani \& Bakhtiarvand (2014) revealed that 55\% of participants agreed with effectiveness of films, videos, CDs, and e-learning on development of their language skills which are parallel with results of present study. According to Kitchakarn (2015), students perceived use of computer technology positively in their listening, speaking, writing, reading skills, and vocabulary knowledge. Nguyen and Tri (2014) reported that students showed their agreement with 
use of ICT (Information Communication Technology) in helping their listening speaking, writing, reading, and grammar and vocabulary knowledge. Regarding behavioural and affective components, findings of the present study were found parallel with some previous research studies (Afshari, Ghavifekr, Siraj, \& Jing, 2013; Kalanzadeh, Soleimani, \& Bakhtiarvand, 2014; Kitchakarn, 2015; Warschauer, 2013). Afshari et al. (2013) showed that perceived usefulness and ease of use influence learners' attitude positively. Kalanzadeh et al. (2014) reported that more than half of participants believed computer-based activities are enjoyable and it was supported by findings of the present study. Like findings of the present study, Kitchakarn (2015) showed that students regarded use of CALL effective on learning different language skills. Warschauer (2013) reported that students feel comfortable and less stress during electronic discussion.

Like behavioural factors of the questionnaire regarding usefulness, facility, and necessity of CALL, open-ended questions results supported some aspects of questionnaire results. Based on results of both quantitative and qualitative studies, participants regarded use of technology on their learning process useful and helpful. Like questionnaire results, open-ended questions results showed that some students but not most of them need technology training courses. Furthermore, results of both studies referred to advantages of CALL and technology use in learning process more than its disadvantages.

Regarding affective factors of the questionnaire including anxiety, eagerness, and attraction, it was found that results of the questionnaire and open-ended questions were in common in many aspects. High percent of students showed learning through computer technology is attractive. In addition, both studies revealed that computer technology motivates learners in their learning process.

Results of the present qualitative study were in line with some previous qualitative research studies. Chen and Kessler (2013) showed that students perceived tablet computers as an advantageous tool in their language learning process because of its easiness to operate. According to Dashtestani (2013), interview results showed that lack of students training and lack of facilities were major obstacles to use electronic dictionaries in the classroom. Results from the study conducted by Liu (2009) revealed that students are aware of advantages of ICT in their learning process.

\section{Conclusion}

This paper has revealed reasons for using computer technology in high school classrooms. It is also suggested that the association of these factors is investigated in future studies. There are indeed challenges and pitfalls in utilizing technology in community high school classes. However, there are also great potential benefits.

The use of computer technology for teaching, learning, practicing and assessing foreign language, like English, has many advantages, particularly in the countries like Iran where EFL learners get very few opportunities for practicing and assessing their language skills communicatively. If EFL teachers and learners wisely capitalize upon these positive aspects of use of computer technology in EFL instruction while teaching, learning and assessing target language, the results would be highly encouraging, productive and profitable for all those associated with these processes. The findings demonstrate that using the computer technology at schools will provide many benefits, as highlighted by:

1. Increased student motivation

2. Greater access to information

3. Ease of learning independently

5. Ease of learning in classroom

6. Covering more materials by computer technology

7. More attraction

8. Variety of resources used (images, videos, applications, etc.)

9. Development of students' computer skills

10. Improved reading experience

Based on the findings of the present study, integration of computer technology in language instruction requires some major factors such as providing enough facilities, holding training courses of computer skills for both teachers and students. Another finding of the study may also suggest that students need to be aware of the advantages of computer technology as learning tool in order to accept it as part of language instruction syllabus. This may help reduce the dehumanizing effect of computer instruction. Students' attitude toward positive effect of CALL on communication skill shows that tendency toward communicative approaches is common among high school students. Unfortunately, grammar translation method is widely used in Iran high schools in which the communicative needs of the students are not taken into account. It is recommended that in integration of computer technology in language instruction, the communicative needs of students to be considered, too.

\section{References}

Afshari, M., Ghavifekr, S., Siraj, S., \& Jing, D. (2013). Students' attitudes towards computer-assisted language learning. Behavioral Sciences, 103, 852-859. 
Aryadoust, V., Mehran, P., \& Alizadeh, M. (2015). Validating a computer-assisted language learning attitude instrument used in Iranian EFL context: an evidence-based approach. Computer Assisted Language Learning, 28(5), 135.

Bramley, D. (2015). Using focus groups for ELT research. Osaka JALT, 98.

Chen, X. B., \& Kessler, G. (2013). Action research tablets for informal language learning: Student usage and attitudes. Language Learning \& Technology, 17(1), 20-36.

Dashtestani, R. (2013). EFL teachers' and students' perspectives on the use of electronic dictionaries for learning English. CALL-EJ, 14(2), 51-65.

Kalanzadeh, G. A., Soleimani, H., \& Bakhtiarvand, M. (2014). Exploring the influence of using technology on Iranian EFL students' motivation. Procedia-Social and Behavioral Sciences, 98, 814-823.

Khaddage, F. (2013). The iPad global embrace are we branding mobilr learning? Proceedings of Society for Information Technology \& Teacher Education International Conference 2013, (pp. 3234-3240). New Orleans.

King, I., \& Bass, D. (2013, March 15). Microsoft's Surface tablet Is said to fall short of predictions. Retrieved December 15, 2015, from Bloomberg L.P.: http://www.bloomberg.com/

Kitchakarn, O. (2015). EFL learners' attitudes towards using computers as a learning tool in language learning. Turkish Online Journal of Educational Technology, 14(2), 52-58.

Liu, J. (2009). A survey of EFL learners' attitudes toward information and communication technologies. English Language Teaching, 2(4), 101-106.

Mackey, A., \& Gass, S. M. (2005). Second Language Research Methodology and Design. New Jersy: Lawrence Erlbaum Associates, Inc.

Nguyen, N. H., \& Tri, D. H. (2014). An exploratory study of ICT use in English language learning among EFL university students. Teaching English with Technology, 4, 32-46.

Oz, H., Demirezen, M., \& Pourfeiz, J. (2015). Digital device ownership, computer literacy, and attitudes toward foreign and computer-assisted language learning. Procedia-Social and Behavioral Sciences, 186, 359-366.

Riasati, M. J., Allahyar, N., \& Tan, K. E. (2012). Technology in language education: Benefits and barriers. Journal of Education and Practice, 3(5), 25-30.

Richards, K. (2009). Trends in qualitative research in language teaching since 2000. Language Teaching, 42(02), 147180 .

Warschauer, M. (2013). Comparing face-to-face and electronic discussion in the second language classroom. CALICO journal, 13(2), 7-26.

Warschauer, M., \& Meskill, C. (2000). Technology and second language teaching. Handbook of Undergraduate Second Language Education. Mahwah, NJ: Lawrence Erlbaum.

Zacharias, N. T. (2012). Qualitative Research Methods for Second Language Education: A Coursebook. Cambridge: Cambridge Scholars.

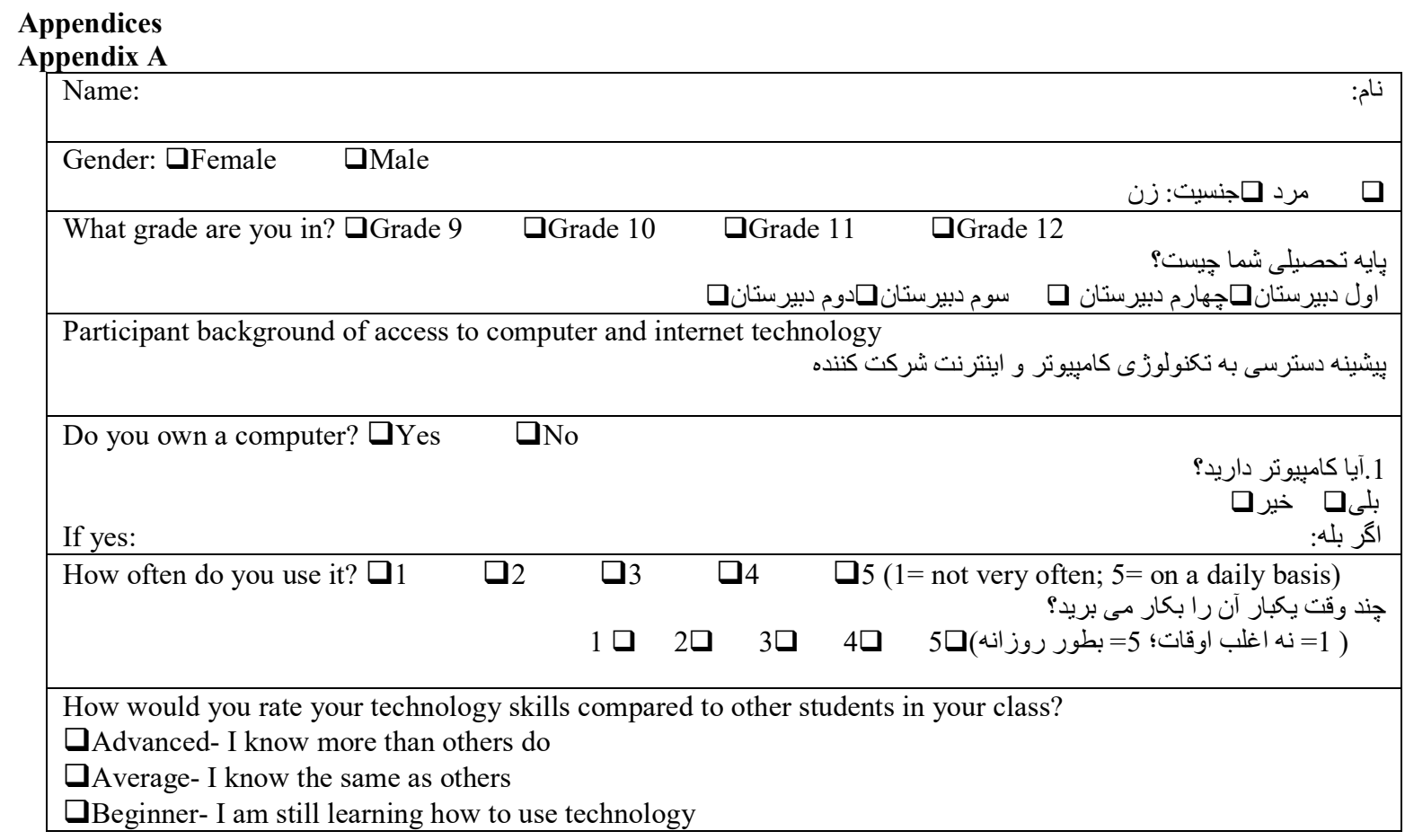




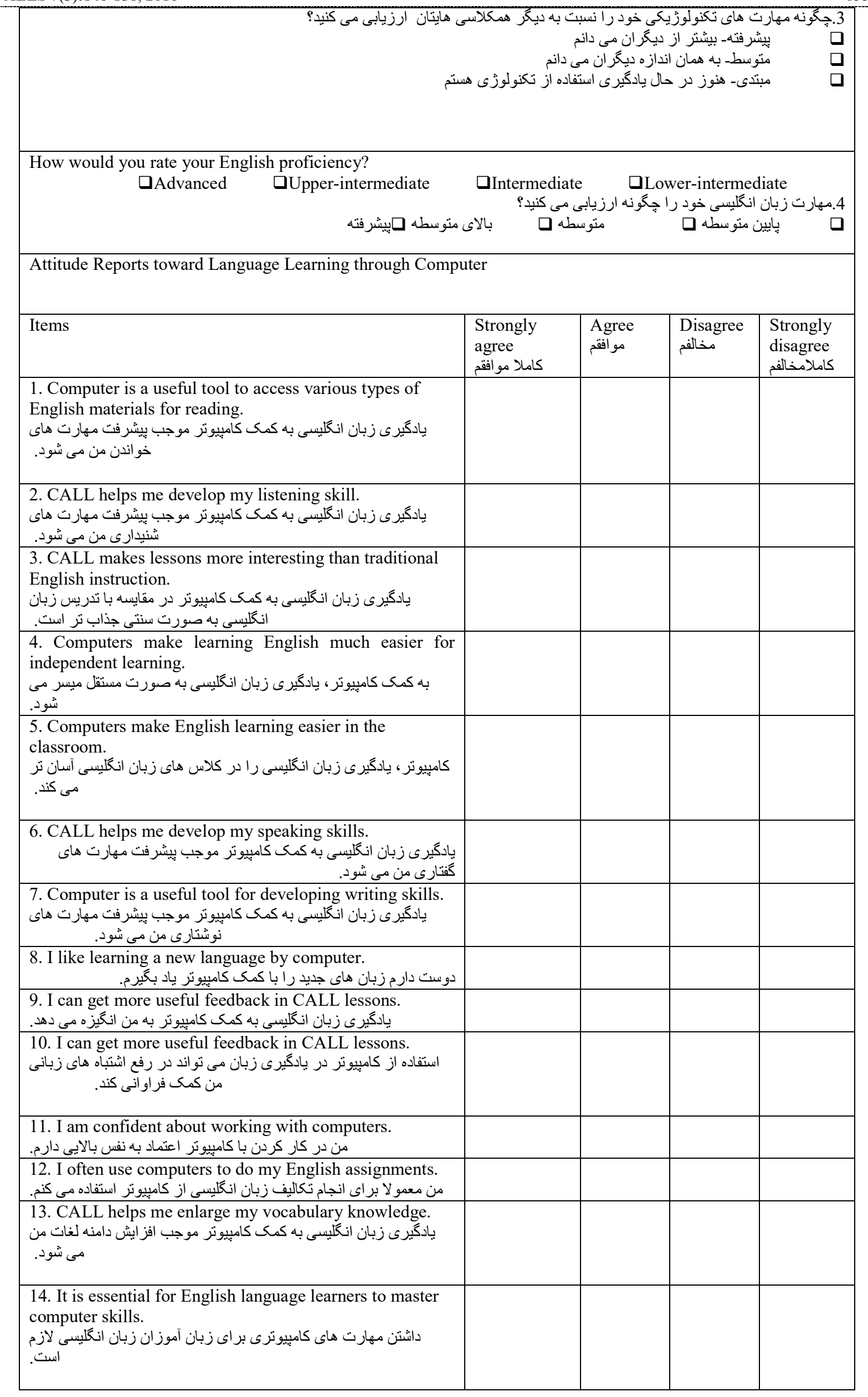


15. Using computer tools to learn English is a great advantage over traditional methods.

ابز ارهاى كامييوترى در مقايسه با روش هاى سنتى مز اياى بيشترى دارد.

16. CALL is a stress-free environment to learn English.

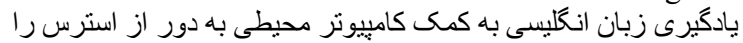

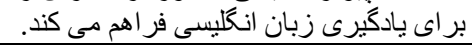

17. Learning English through computers is not necessary. يادكيرى زبان از طريق كاميبيونز ضرورتى ندارد.

18. I find that using computers does not help my English learning.

استفاده از كامييوتر كمكى به يادكيرى زبان انكليسى نمى كند.

19. The use of computer can help improve my communication skills.

استفاده از كامييوتر موجب يِيشرفت مهارت هاى ارتباطى درزبان انكليسى

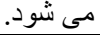

20. Using a computer makes language lessons more interesting to me.

استفاده از كامييوتر يادكيرى زبان انكليسى را براى من جذاب تر مى كند.

21. CALL helps me develop my grammar.

استفاده از كامييوتر در يادكيرى زبان انكليسى، سبب مى شود كه اطلاعات

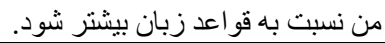

22. CALL makes me feel tense and uncomfortable.

يادكيرى زبان به كمى كامييوتر من را عصبى و نار احت مى كند.

23. Communicating by e-mail is a good way to improve my English.

ارتباط از طريق ايميل موجب يِشرفت زبان انكليسى من مى شود.

24. I need training in using language learning software programs.

من براى استفاده از برنامه هاى نرم افزارى آموزش زبان نياز به آموزش

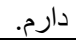

25. Chatting with native English speakers on the internet is helpful for learning English.

جت كردن با افر اد انكليسى زبان در اينترنت براى يادگيرى زبان انكليسى مفيد است.

26. I can cover more material on my own when I study English with computers.

يادكيرى زبان از طريق كامييوتر ، سبب مى شود كه مطالب بيشترى را مطالعه كنم.

27. Computers will dehumanize learning English. يادكيرى زبان انكليسى به كمى كامييوتر حس طبيعى مانند يادكيرى در

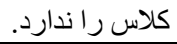

Open-Ended Questions

1) What type of technology user are you? Advanced, average, or beginner?

1. جها نوع كاربر تكنولوزى هستيد؟ بِيشرفته، متوسط، يا مبتدى؟

2) What types of electronic devices do you use in your daily life?

$$
\text { 2. جهاه نوع وسيله هاى الكترونيكى در زندكى روزمره خود استفاده مى كنيد؟ }
$$

3.جُكونه از تكنولوزى براى انجام تكاليف درس زبان انكليسى استفاده مى كنيد؟

3) How do you use technology for English home works?

4.بعضى از موانع اصلى استفاده از تكنولوزى در مدرسه شما جه هستند؟

4) What are some major obstacles to using technology in your school?

$$
\text { 5.جُونه مدرسه شما مى تو اند كار كردن بطور الكترونيكى را براى شما آسانتر كند؟ }
$$

5) How could your school make it easier for you to work electronically?

$$
\text { 6. به نظر شما، كدام يك از مهارت يا دانش زبانى مى تو اند از طريق ابز ار تكنولوزيكى تقويت شود؟ با دليل توضيح دهيد. }
$$

6) In your opinion, which language skills or knowledge can be improved through technology devices? Can you give reasons?

$$
\text { 7.مزيت هاو نقاط ضعف استفاده از نكنولوزى در بادكيرى زبان انكليسى جه هستند؟ }
$$

7) What are the advantages and disadvantages of using technology programs in language instruction? 